\title{
Effect of Gamma Irradiation on the Physical Stability of DPPC Liposomes
}

(Kesan Sinaran Gama ke atas Kestabilan Fizikal Liposom DPPC)

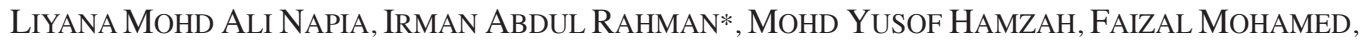 \\ Hur MunaWAR KabIR MOHD, InTAN SYAKEEla AHMAD BASTAMAM, SHAMELlia SHARIN, \\ NORSYAHIDAH MOHD HIDZIR \& SHAHIDAN RADIMAN
}

\begin{abstract}
Unilamellar liposomes composed of dipalmitoylphosphatidylcholine (DPPC) were prepared by the reverse-phase evaporation method and extrusion through a polycarbonate membrane filter. Liposomes at $0.7 \mathrm{mg} / \mathrm{mL}$ lipid concentration in deionized water were exposed to gamma irradiation at a dose in the range 0.5 to $25 \mathrm{kGy}$. Gamma irradiation of liposomes resulted in the degradation of DPPC lipids into free fatty acids, lysophosphatidylcholine and 1,2-palmitoylphosphatidic acid (DPPA). The effect of gamma irradiation towards the physical stability of liposomes was investigated by means of dynamic light scattering (DLS), transmission electron microscopy (TEM) and zeta potential analysis. From the DLS analysis, no significant changes were observed in the hydrodynamic size of liposomes. TEM images indicate that the liposomes surface became smoother and rounder as higher irradiation doses were applied. Zeta potential analysis showed that gamma irradiation of DPPC liposomes at radiation doses as low as $0.5 \mathrm{kGy}$ resulted in a drastic rise in the magnitude of the zeta potential. The results also demonstrate that gamma irradiation of liposomes suspension enhanced the overall stability of liposomes. Hence, it can be concluded that gamma irradiation on DPPC liposomes may potentially produce liposomes with higher stability.
\end{abstract}

Keywords: Dipalmitoylphosphatidylcholine (DPPC); gamma irradiation; physical stability; zeta potential

\section{ABSTRAK}

Liposom unilamela yang terbentuk daripada lipid dipalmitoilfosfatidilkolina (DPPC) telah dihasilkan menggunakan kaedah penyejatan fasa-berbalik dan penerobosan menerusi turas membran polikarbonat. Ampaian liposom dengan kepekatan lipid $0.7 \mathrm{mg} / \mathrm{mL}$ di dalam air ternyah ion dipancarkan sinaran gama pada dos 0.5 hingga $25 \mathrm{kGy}$. Penyinaran gama ke atas liposom menyebabkan degradasi lipid DPPC kepada asid lemak bebas, lisofosfatidilkolina dan 1,2-palmitoil-asid fosfatidik (DPPA). Kesan penyinaran gama terhadap kestabilan fizikal liposom dikaji menggunakan analisis penyerakan cahaya dinamik (DLS), mikroskop elektron transmisi (TEM) dan penganalisis keupayaan zeta. Daripada analisis DLS, tiada perubahan pada saiz liposom dapat dikenal pasti. Imej TEM menunjukkan bahawa permukaan liposom semakin licin dan semakin membulat apabila semakin tinggi dos penyinaran dikenakan ke atas liposom. Analisis keupayaan zeta mendedahkan bahawa penyinaran gama ke atas liposom DPPC pada dos serendah 0.5 kGy menyebabkan peningkatan drastik terhadap magnitud keupayaan zeta. Hasil analisis ini juga menunjukkan bahawa penyinaran gama ke atas ampaian liposom berupaya untuk meningkatkan kestabilan liposom. Oleh itu, penyinaran gama ke atas liposom DPPC boleh menghasilkan liposom yang berkestabilan tinggi.

Kata kunci: Dipalmitoilfosfatidilkolina (DPPC); kestabilan fizikal; keupayaan zet; penyinaran gama

\section{INTRODUCTION}

The effects of gamma irradiation on the overall chemical structure of liposomes have been extensively investigated to understand its influence on biological systems (Albertini \& Rustichelli 1993; Erdogan et al. 2006; Hur Munawar et al. 2013; Pamplona 2008; Schneider 2009; Stark 1991; Van der Paal et al. 2016). The understanding of such mechanisms is vital, because liposomes represent a good model in the study of the effect of radiation on food, cells as well as sterilization of drug carriers. Studies on the effect of gamma irradiation on dipalmitoylphosphatidylcholine (DPPC) and hyaluronic acid (HA) and the manner in which the irradiation changes the interaction between these two components has also been thoroughly investigated (Ainee Fatimah et al.2015). In spite of all the effort done in prior work, results on physico-chemical changes, especially ones affected by irradiation-damage are still lacking, thus hindering the application of liposomes as drug carriers and the utilization of irradiation to sterilize liposomes.

Liposomes, upon irradiation with gamma rays, are subjected to direct or indirect effects. Direct effects are usually associated with the degradation of chemical bonds, while indirect effects are caused by radicals formed from radiolysis of water. In the former process, liposomes directly absorb irradiation energy, resulting in chemical chain-scissioning. On the other hand, in the latter 
process, the main products of water radiolysis radicals such as hydrogen atoms, solvated electrons and hydroxyl radicals, may attack the liposome and cause radiation damage. Since the amount of energy absorbed by each component in a liposome-water system is proportional to the individual electron fraction (which is directly related to the mass fraction) in a dilute liposome aqueous solution, the indirect effect of gamma irradiation prevails (Ulanski \& Rosiak 1999). Apart from irradiation-damage, other modes of damage can also be expected from hydrolysis and dehydrogenation.

Tinsley and Maerker (1993) and Zuidam et al. (1996) characterized the formation of dipalmitoylphosphatidic acid (DPPA) from dipalmitoylphosphatidylcholine (DPPC) and lysophospholipids, following exposure to gammairradiation, as well as factors affecting radiation-damage such as type of phospholipids, type of buffer solution, size and concentration.

However, in spite of these contributions, there remain gaps in understanding how liposomes are affected by gamma irradiation. The aim of this work was to investigate the chemical, size, size distribution and morphological changes, as well as the stability of DPPC liposomes after exposure to gamma irradiation. This would provide fundamental knowledge on the degradation process that could be useful in formulating and decorating liposomes into polymer caged liposomes (PCL) using an irradiation induced method.

\section{MATERIALS AND METHODS}

\section{MATERIALS}

1,2-dipalmitoyl-sn-glycero-3-phosphocholine (DPPC) lipid was purchased from Avanti Polar Lipid Inc., which is readily dispersed in chloroform at a concentration of $25 \mathrm{mg} / \mathrm{mL}$. The lipid was used without prior purification.

\section{PREPARATION AND IRRADIATION OF LIPOSOMES}

DPPC liposomes were prepared by a reverse-phase evaporation method, as introduced by Szoka and Papahadjopoulos (1978). Briefly, lipid dispersion was diluted to a concentration of $10 \mathrm{mg} / \mathrm{mL}$ before a small amount of deionized water was added into the solution. The mixture was then subjected to sonication for 5-10 min, until a homogenous milky dispersion obtained. At this point, inverted micelles were formed. Next, the solvent and a small amount of aqueous solution were removed using an oven at $55^{\circ} \mathrm{C}$ for $24 \mathrm{~h}$ to form a lipid film. The lipid film was rehydrated at $50^{\circ} \mathrm{C}$ with deionized water for 10-15 min and vigorously mixed to obtain a homogenous dispersion of liposomes. The liposomes suspension was extruded 13 times through a polycarbonate membrane filter (Millipore, Temecula, CA, USA) with pore sizes of $100 \mathrm{~nm}$. The final concentration of lipid in the solution was $0.7 \mathrm{mg} /$ $\mathrm{mL}$. Liposomes suspension were irradiated at $0.5,5,15,20$ and $25 \mathrm{kGy}$ using a Cobalt-60 source with a dose rate of
23.06 Gymin ${ }^{-1}$ at the School of Applied Physics, Universiti Kebangsaan Malaysia. Prior to irradiation, all the samples were degassed by purging nitrogen through for $15 \mathrm{~min}$.

\section{CHARACTERIZATION}

The FTIR technique was used to study radiation-induced chemical changes of DPPC liposomes by using a Perkin Elmer Spotlight 400 FT-IR Imaging System Spectrometer (Model 1720X, USA). A study on the physical stability of liposomes was carried out by using the Dynamic Light Scattering (DLS) technique and zeta potential measurement. Both analyses were performed with Zetasizer Nano ZS (Malvern Instruments, UK). For morphology studies of liposomes, measurement by transmission electron microscope (TEM) (Philips TEM CM12) was performed on liposomes stained with uranyl acetate (4 wt. \%).

\section{RESULTS AND DISCUSSION}

\section{GAMMA IRRADIATION INDUCED DAMAGE OF LIPOSOMES}

The normalized FTIR spectra of non-irradiated DPPC liposomes and irradiated DPPC liposomes at doses of 0.5 and $25 \mathrm{kGy}$ is shown in Figure 1(a) (fingerprint region is shown in Figure 1(b)). The representative bands of FTIR spectra are shown in Table 1. The FTIR spectra demonstrated no loss nor addition of new major peaks in the irradiated samples spectrum. However, changes in peak intensity can be observed at 1416, 1220-1242, 1170, 1088, 1060 and $816 \mathrm{~cm}^{-1}$ bands. An increase in intensity of the peak at $1416 \mathrm{~cm}^{-1}$ from irradiated samples is attributable to COO symmetric stretch, due to the presence of carbonyl group. The increase in carbonyl group concentration in the samples is contributed by the formation of free fatty acids. An increase in peak intensity at $1170 \mathrm{~cm}^{-1}$, which can be assigned to the $\mathrm{C}-\mathrm{OH}$ stretching, is also due to the production of fatty acids, lysophosphatidylcholine (LPC) and 1,2-palmitoyl-phosphatidic acid (DPPA). A decrease in the intensity of peaks at 1220-1242, 1088, 1060 and $816 \mathrm{~cm}^{-1}$ is due to an alteration of the bonds present in the phosphorus. The C-O-P-O-C bond in non-irradiated DPPC was altered into $\mathrm{C}-\mathrm{O}-\mathrm{P}-\mathrm{O}-\mathrm{H}$ due to the degradation of DPPC into 1,2-palmitoyl-phosphatidic acid (DPPA) and lysophosphatidic acid (LPA). The FTIR results generally suggest that LPC, LPA, DPPA and free fatty acids were all present in the irradiated samples - an observation that matches perfectly with that made by Tinsley and Maerker (1993) and Zuidam et al. (1996). These products may result from the hydrolysis process of DPPC (Vernooij et al. 2002). However, it was proven in reports by Grit et al. (1993a, 1993b, 1993c), that hydrolysis in a storage medium yielded a very low amount $(<1 \%)$ of LPC when DPPC was exposed to gamma rays; indicating that hydrolysis is not the primary mode of degradation in the application of gamma irradiation. Additionally, the degradation route in this study can be explained as follows: As the irradiated samples were diluted, 


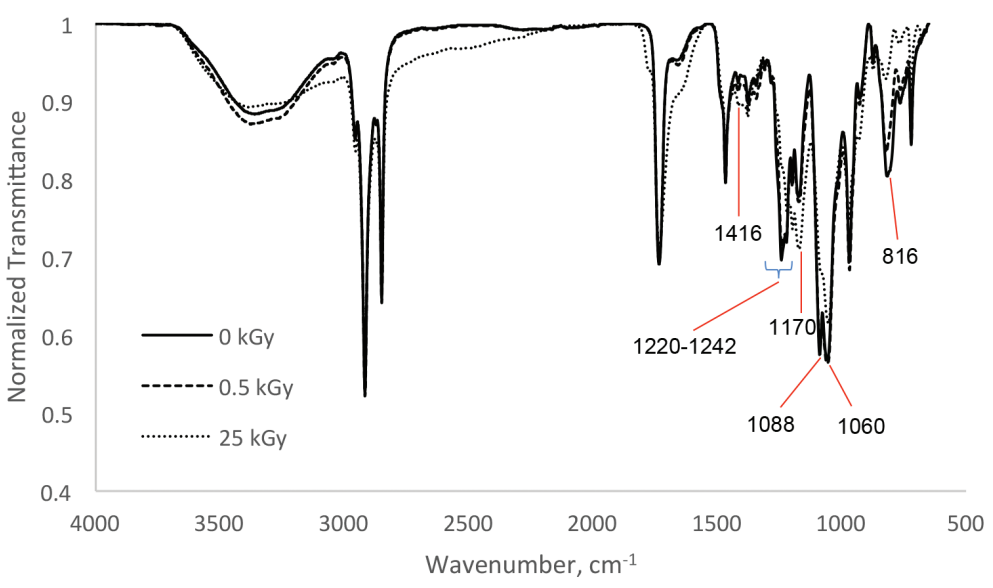

FIGURE 1. a) FTIR spectra of non-irradiated and irradiated DPPC at doses of 0.5 and $25 \mathrm{kGy}$

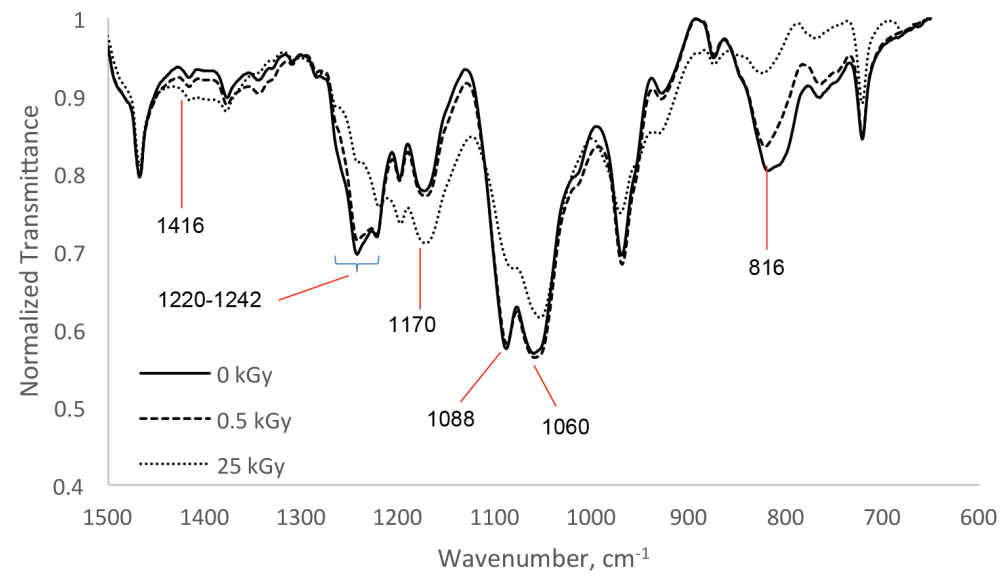

FIGURE 1. b) FTIR spectra of non-irradiated and irradiated DPPC at doses of 0.5 and $25 \mathrm{kGy}$ (fingerprint region)

irradiation damage is mainly caused by indirect effect of gamma irradiation, where $\mathrm{OH}$ radicals from water radiolysis attack the liposomes on the bilayer surface (Barber \& Thomas 1978).

TABLE 1. Representative bands of FTIR spectra for DPPC and their assignment

\begin{tabular}{cl}
\hline $\begin{array}{c}\text { Wavenumber } \\
\left(\mathrm{cm}^{-1}\right)\end{array}$ & \multicolumn{1}{c}{ Vibrational assignment } \\
\hline 3323 & $\mathrm{OH}$ stretching \\
2917 & $\mathrm{CH}_{2}$ antisymmetric stretching \\
2850 & $\mathrm{CH}_{2}$ symmetric stretching \\
1735 & $\mathrm{C}=\mathrm{O}$ carbonyl stretch \\
1467 & $\mathrm{C}-\mathrm{C}$ bending \\
1416 & $\mathrm{COO}$ symmetric stretch \\
$1220-1242$ & antisymmetric double stretching \\
1170 & $\mathrm{C}-\mathrm{OH}$ stretching \\
1088 & $\mathrm{CO}$ stretching \\
1060 & symmetric stretching \\
970 & $\mathrm{~N}^{+}\left(\mathrm{CH}_{3}\right)_{3}$ group antisymmetric stretching \\
816 & $\mathrm{PO}$ stretching \\
\hline
\end{tabular}

\section{EFFECT OF GAMMA IRRADIATION ON THE SIZE OF LIPOSOMES}

Dynamic light scattering measurement data of nonirradiated and irradiated liposomes are shown in Table 2. The z-average sizes of the non-irradiated and irradiated DPPC liposomes were found to be within the range of 104-126 nm. The PDI value $(<0.2)$ and size distribution graph (Figure 2), respectively, showed that the samples were monodispersed. There were no significant changes observed in terms of the average size and size distribution of liposomes after gamma irradiation. This suggests that the exposure of liposomes to gamma irradiation at doses ranging from 0 to $25 \mathrm{kGy}$ only affected the material in terms of chemical changes, i.e., the accumulation of degradation products (fatty acids and lysolipids) packed in the lipid bilayer, leading to an increase in the packing density of DPPC (Szczes 2016). The packing of the lipid bilayer could possibly be assisted by the repulsion forces from the $-\mathrm{COOH}$ group that protonated into ${ }^{-\mathrm{COO}^{-}}$on the liposomes surface, explaining the insignificant change in term of size. Hence, gamma irradiation at doses up to $25 \mathrm{kGy}$ on DPPC liposomes has no effect on the average particle size of the liposomes. 
TABLE 2. Z-average size and polydispersity index (PDI) of liposomes

\begin{tabular}{ccc}
\hline Irradiation dose $(\mathrm{kGy})$ & Particle size $(\mathrm{nm})$ & PDI \\
\hline Non-irradiated & $104.6 \pm 32.0$ & 0.080 \\
0.5 & $119.3 \pm 38.0$ & 0.086 \\
5 & $115.8 \pm 36.7$ & 0.086 \\
15 & $125.3 \pm 39.8$ & 0.085 \\
20 & $119.6 \pm 39.0$ & 0.089 \\
25 & $114.2 \pm 37.9$ & 0.092 \\
\hline
\end{tabular}

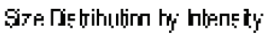

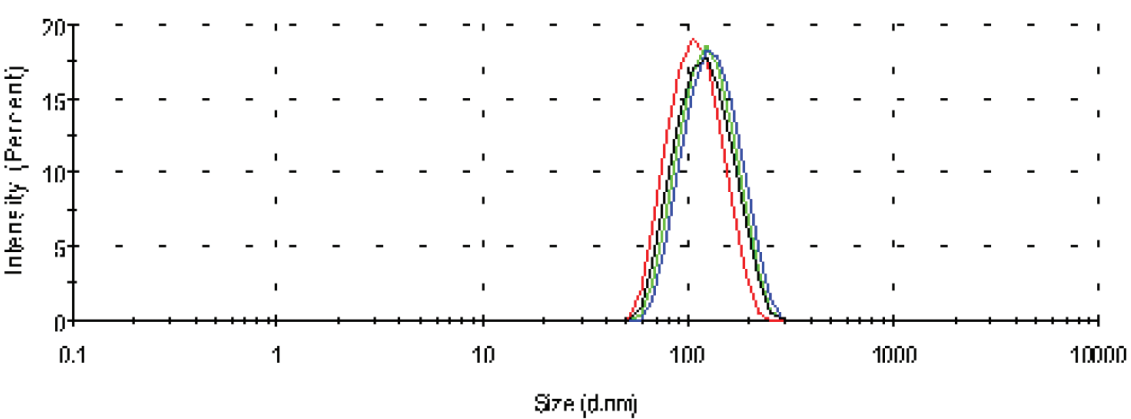

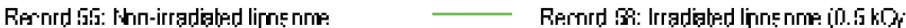

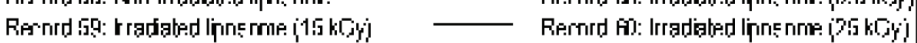

FIGURE 2. Size distribution of non-irradiated liposomes and irradiated liposomes at 0.5, 15 and $25 \mathrm{kGy}$

EFFECT OF GAMMA IRRADIATION ON THE MORPHOLOGY OF LIPOSOMES

TEM images of non-irradiated and irradiated DPPC liposomes at doses of 0.5 and $25 \mathrm{kGy}$ are shown in Figure 3(a)-3(c). The images show that both non-irradiated and irradiated liposomes are spherical in shape. The size of the liposomes, as shown in the TEM images, compliment the data on average size of liposomes acquired from
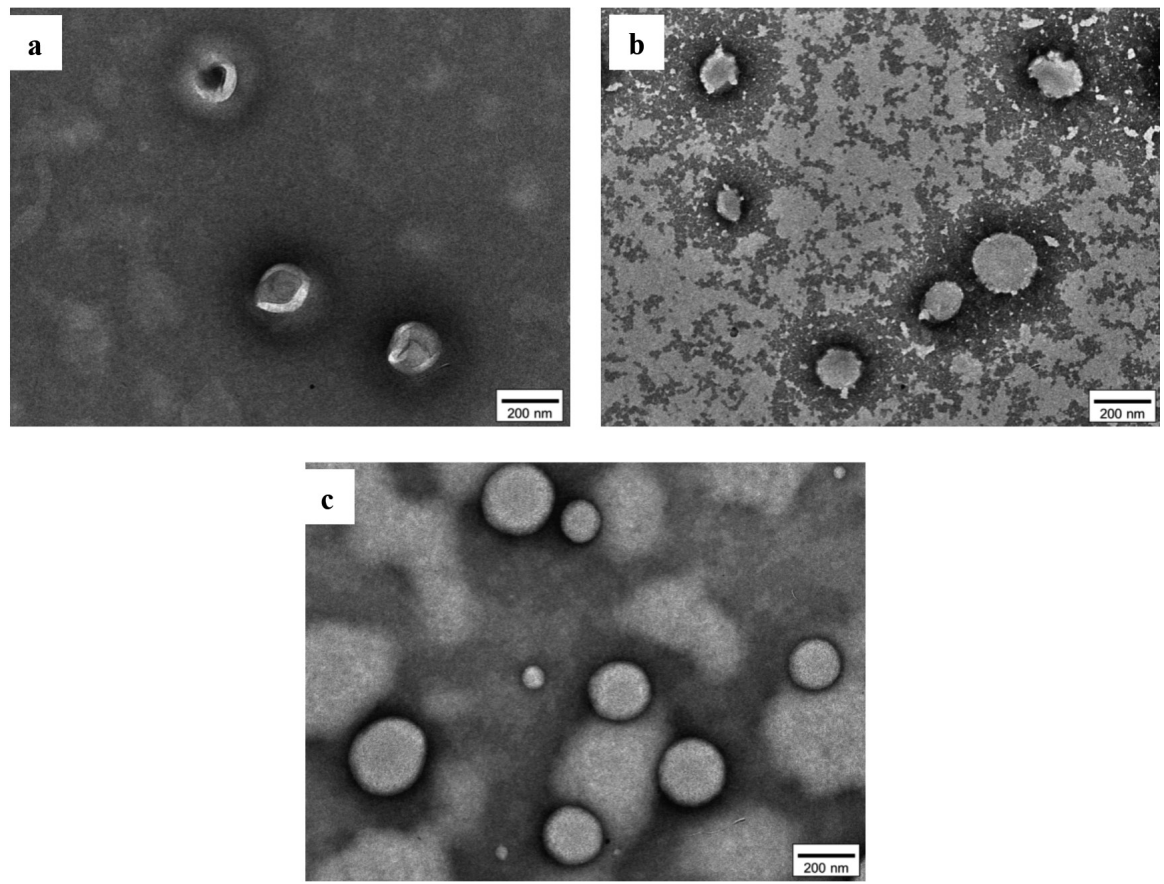

FIGURE 3. TEM images of samples (mag. 13000×). (a) non-irradiated DPPC liposomes, (b) DPPC liposomes irradiated at $0.5 \mathrm{kGy}$ and (c) DPPC liposomes irradiated at $25 \mathrm{kGy}$ 
DLS measurements. Higher irradiation doses resulted in a smoother surface and rounder liposomes. Again, the smoother and rounder surfaces on the liposomes can be explained by the formation of $-\mathrm{COOH}$ group on the liposome surfaces, i.e., the repulsion forces hold the outer layer of the liposomes, in spite of growing pressure from the inside, since accumulated degradation products (fatty acids and lysolipids) are packed in the lipid bilayer (Szczes 2016).

\section{EFFECT OF GAMMA IRRADIATION ON THE STABILITY OF LIPOSOMES}

Figure 4 shows the effect of absorbed irradiation doses on the stability of the liposomes suspension. Zeta potential is a measure of the stability of the particle system; higher zeta potential values denote higher liposomes stability. In this study, zeta potential data of the liposomal dispersion suggest that exposure to gamma irradiation increases the overall liposomes stability. The increment of zeta potential values can be explained in terms of the formation of $\mathrm{COOH}$ groups on the outer layer of the liposomes, which resulted by the degradation of DPPC into lysophospholipids and fatty acids. As the - $\mathrm{COOH}$ groups are protonated to - $\mathrm{COO}^{-}$, a layer of negative charge is formed on the individual liposomes. Consequently, as individual liposomes are layered with the same charge (negative), repulsion forces between liposomes keep them apart, thus rendering a stabilizing effect. Additionally, in this case, the inherent zeta potential value is around $-14 \mathrm{mV}$ and irradiation at $0.5 \mathrm{kGy}$ increased the value up to nearly $-50 \mathrm{mV}$. At higher doses of up to $25 \mathrm{kGy}$, the zeta potential values stabilize in the range of -60 to $-66 \mathrm{mV}$. This suggests that a maximum amount of $-\mathrm{COOH}$ group has been achieved.

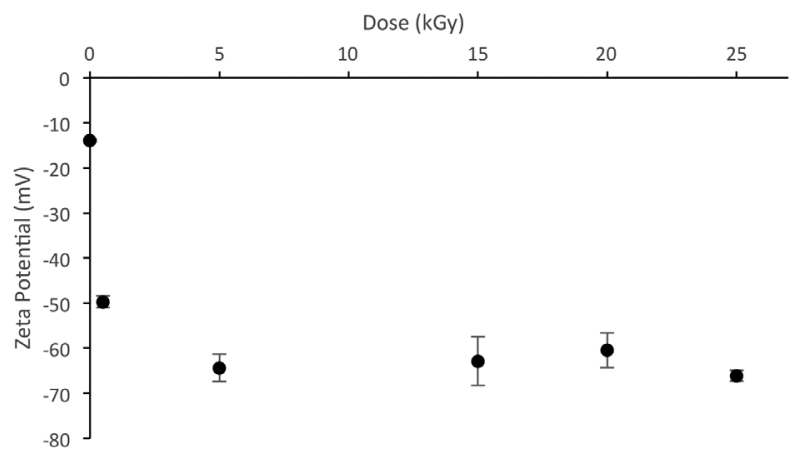

FIGURE 4. Effect of irradiation dose on zeta potential of DPPC liposomes

\section{CONCLUSION}

In this study, liposomes composed of DPPC, a saturated phospholipid were irradiated with gamma irradiation to investigate the effect of the latter towards the degradation route, size and size distribution, morphology and the stability of the liposomes. Chemical changes as shown by FTIR data suggest that there is an increase in - $\mathrm{COOH}$ group on the surface of the liposomes following exposure to gamma radiation. The formation of the $-\mathrm{COOH}$ group plays a significant role in retaining the size of the liposomes, in spite of the loading of lysophospholipids and fatty acids in the liposomes bilayer. The same factor also contributes to a smoother and rounder surface, as well as in a higher stability of the liposomes. All the changes as shown in this study suggested that irradiation damage due to gamma rays has preferable effects that can be manipulated to improve the properties of the liposomes. This knowledge can be applied in formulating polymer-caged liposomes (PCL) in that a safe range of doses is now known. Furthermore, the availability of $-\mathrm{COOH}$ can be utilized for ligands attachment.

\section{ACKNOWLEDGEMENTS}

The authors would like to acknowledge the financial support from Universiti Kebangsaan Malaysia through grant GUP-2016-010 and GP-K012225.

\section{REFERENCES}

Ainee, F.A., Irman, A.R., Hur Munawar, K.M., Faizal, M., Shahidan R. \& Muhamad S.Y. 2015. Interaction of hyaluronic acid (HA) with dipalmitoylphosphatidylcholine (DPPC) and its effect on the stability of HA-lipid to gamma irradiation. Malaysian Journal of Analytical Sciences 19(1): 173-178.

Albertini, G. \& Rustichelli,F. 1993. Effects of gamma irradiation on the liposomal structure. Liposome Technology. 2nd ed. edited by Gregoriadis, G. Boca Raton: CRC Press. 1: 399429.

Barber, D.J.W. \& Thomas, J.K. 1978. Reactions of radicals with lecithin bilayers. Radiation Research 74(1): 51-65.

Erdogan, S., Ozer, A.Y., Ekizoglu, M., Ozalp, M., Colak, S. \& Korkmaz, M. 2006. Gamma irradiation of liposomal phospholipids. FABAD J. Pharm. Sci. 31: 182-190.

Grit, M., Underberg, W.J.M. \& Crommelin, D.J.A. 1993a Hydrolysis of saturated soybean phosphatidylcholine in aqueous liposome dispersions. Journal of Pharmaceutical Sciences 82(4): 362-366.

Grit, M., Zuidam, N.J. \& Crommelin, D.J.A. 1993b. Analysis and hydrolysis kinetics of phospholipids in aqueous liposome dispersions. Liposome Technology. 2nd ed. edited by Gregoriadis, G. Boca Raton: CRC Press. 1: 455-487.

Grit, M., Zuidam, N.J., Underberg, W.J.M. \& Crommelin, D.J.A. 1993c. Hydrolysis of partially saturated egg phosphatidylcholine in aqueous liposome dispersions and effect of cholesterol incorporation on hydrolysis kinetics. Journal of Pharmacy and Pharmacology 45(6): 490-495.

Hur, M.K.M., Ainee, F.A., Faizal, M., Nursaidatul, S.K., Ng, W.L., Poh, R.J., Muhamad, S.Y., Mohd, H.M.I., Suria, R., Shahidan, R. \& Irman, A.R. 2013. The effect of gamma irradiation on the chemical structure and surface characteristics of dipalmitoyl phosphatidylcholine (DPPC) Malaysian Journal of Analytical Sciences 17(3): 454-460.

Pamplona, R. 2008. Membrane phospholipids, lipoxidative damage and molecular integrity: A causal role in aging and longevity. Biochimica et Biophysica Acta (BBA)Bioenergetics 1777(10): 1249-1262.

Schneider, C. 2009. An update on products and mechanisms of lipid peroxidation. Molecular Nutrition \& Food Research 53(3): 315-321. 
Stark, G. 1991. The effect of ionizing radiation on lipid membranes. Biochimica et Biophysica Acta 1071: 103-122.

Szczes, A. 2016. Effect of the enzymatically modified supported dipalmitoylphosphatidylcholine (DPPC) bilayers on calcium carbonate formation. Colloid and Polymer Science 294(2): 409-419.

Szoka, F. \& Papahadjopoulos, D. 1978. Procedure for preparation of liposomes with large internal aqueous space and high capture by reverse-phase evaporation. Proceedings of the National Academy of Sciences 75(9): 4194-4198.

Tinsley, P.W. \& Maerker, G. 1993. Effect of low-dose $\gamma$-radiation on individual phospholipids in aqueous suspension. Journal of American Oil Chemists' Society 70(2): 187-191.

Ulanski, P. \& Rosiak, J.M. 1999. The use of radiation technique in the synthesis of polymeric nanogels. Nuclear Instruments and Methods in Physics Research B: Beam Interactions with Materials and Atoms 151(1): 356-360.

Van der Paal, J., Neyts, E.C., Verlackt, C.C.W. \& Bogaerts, A. 2016. Effect of lipid peroxidation on membrane permeability of cancer and normal cells subjected to oxidative stress. Chemical Science 7(1): 489-498.

Vernooij, E.A.A.M., Bosch, J.J.K. \& Crommelin, D.J.A. 2002. Fourier transform infrared spectroscopic determination of the hydrolysis of poly (ethylene glycol)phosphatidylethanolamine-containing liposomes. Langmuir 18(9): 3466-3470.

Zuidam, N.J., Versluis, C., Vernooy, E.A.A.M. \& Crommelin, D.J.A. 1996. Gamma-irradiation of liposomes composed of saturated phospholipids. Effect of bilayer composition, size, concentration and absorbed dose on chemical degradation and physical destabilization of liposomes. Biochimica et Biophysica Acta (BBA)-Biomembranes 1280(1): 135-148.
Liyana Mohd Ali Napia, Irman Abdul Rahman, Faizal Mohamed, Hur Munawar Kabir Mohd, Intan Syakeela Ahmad Bastamam, Shamellia Sharin, Norsyahidah Mohd Hidzir \& Shahidan Radiman School of Applied Physics Faculty of Science and Technology

Universiti Kebangsaan Malaysia 43600 UKM Bangi, Selangor Darul Ehsan Malaysia

Irman Abdul Rahman*, Faizal Mohamed, Norsyahidah Mohd Hidzir \& Shahidan Radiman

Nuclear Technology Research Center

School of Applied Physics

Faculty of Science and Technology

Universiti Kebangsaan Malaysia 43600 UKM Bangi, Selangor Darul Ehsan

Malaysia

Mohd Yusof Hamzah

Nanotechnology Laboratory

Radiation Technology Division

Agensi Nuklear Malaysia

43000 Kajang, Selangor Darul Ehsan

Malaysia

*Corresponding author; email: irman@ukm.edu.my

Received: 15 September 2016

Accepted: 17 March 2017 